\title{
Exploring Kotagede's Traditional Culinary Tourism Strategy as a Culture And Tourism Reinforcement in Yogyakarta
}

\author{
Insanul Qisti Barriyah, Moh. Rusnoto Susanto, Rahayu Retnaningsih, Bambang Trisilo \\ Dewobroto, Sugiyamin, Anselmus Sudirman \\ \{insanul_qisti@ustjogja.ac.id ${ }^{1}$, rusnoto@ustjogja.ac.id ${ }^{2}$,rahayu@ustjogja.ac.id ${ }^{3}$, \\ gajahdewo@yahoo.co.id ${ }^{4}$, sugiyamin@gmail.com ${ }^{5}$, anselmus.sudirman@ustjogja.ac.id $\left.{ }^{6}\right\}$ \\ Program Studi Pendidikan Seni Rupa, Universitas Sarjanawiyata Tamansiswa, Yogyakarta- \\ Indonesia $^{1,2,4,5}$, Program Pascasarjana, Universitas Negeri Yogyakarta, Yogyakarta-Indonesia ${ }^{3}$, Program \\ Studi Pendidikan Bahasa Ingris, Universitas Sarjanawiyata Tamansiswa, Yogyakarta-Indonesia ${ }^{6}$
}

\begin{abstract}
As a potential tourist destination, Yogyakarta has Kotagede, one of the most popular tourist areas due to its traditional and historical tourism. It is popular for its beauty and traditional crafts (silver jewelry crafts and culinary traditions of the colonial era). The culinary potential is currently managed and developed as an alternative tourist attraction enriched with cultural nuances, historical, and educational tourism. The Indonesian culinary is one of the urgent heritages that should be developed further, otherwise it is abandoned by our own nation. This is a glaring fact that strengthens the exploration of information and studies on culinary potential to support a cultural atmosphere in the Kotagede region. The research method or approach is mainly concerned with a profile and a reality using qualitative quantum horizons. The research method or approach is based on a more deeply identification of traditional culinary culture, and observed realities. This research is intended to describe phenomena experienced by research subjects in terms of behaviors, perceptions, motivations, actions, etc., holistically, and with a special natural context. The development of a culinary potential in the Kotagede tourism illustrates representation, regulation, consumption and production. Kotagede's traditional food currently represents a resistance of the community that shows backgrounds of social, economic and consumer groups.
\end{abstract}

Keywords: Culinary tourism, local wisdom, culture, tourism.

\section{Introduction}

Tourism is a vital sector that supports an increasing growth of economy for the provision of employment. It is also a socio-cultural development that promotes the tourism image to foreign nations. Tourism is a source of income after oil and gas. In other words, tourism in Indonesia is a potential sector to develop, and this sector is expected to be the best among the foreign exchange earners. 


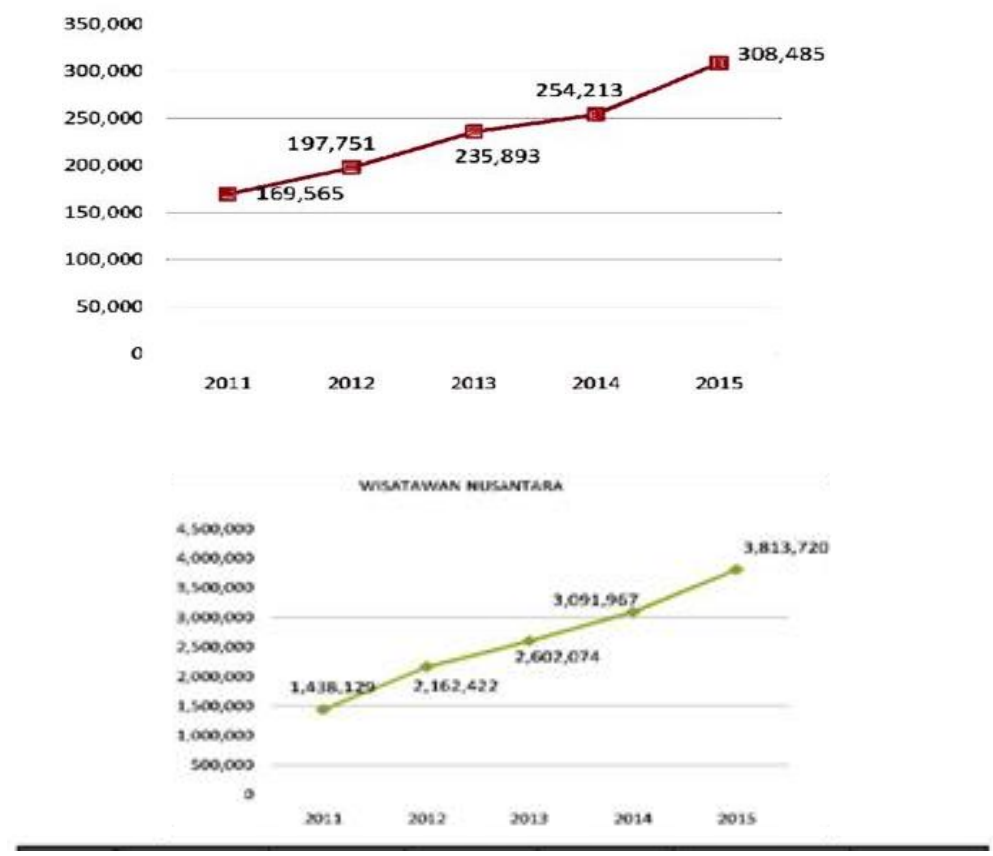

Fig. 1. A Graph of Tourist Development in the Special Region of Yogyakarta (Source: Tourism Statistics Data: 2015)

Table 1. Tourist Development in the Special Region of Yogyakarta (Source: Tourism Statistics Data:

\begin{tabular}{ccccccc}
\hline Year & $\begin{array}{c}\text { Foreign } \\
\text { Tourist }\end{array}$ & $\begin{array}{c}\text { Growth } \\
(\boldsymbol{\%})\end{array}$ & $\begin{array}{c}\text { Local } \\
\text { tourist }\end{array}$ & $\begin{array}{c}\text { Growth } \\
(\boldsymbol{\%})\end{array}$ & Total & $\begin{array}{c}\text { Growth } \\
(\boldsymbol{\%})\end{array}$ \\
\hline 2011 & 169565 & 9.57 & 1438129 & 1.37 & 1607694 & 2.17 \\
2012 & 197751 & 16.62 & 2162422 & 50.36 & 2360173 & 46.80 \\
2013 & 235893 & 19.29 & 2602074 & 20.33 & 2837967 & 20.24 \\
2014 & 254213 & 7.77 & 3091967 & 18.83 & 3346180 & 17.91 \\
2015 & 308485 & 21.35 & 3813720 & 23.34 & 4122205 & 23.19 \\
\hline
\end{tabular}

As a tourism city, Yogyakarta illustrates a potential city development in the world of tourism. Yogyakarta is the second largest tourist destination in Indonesia after Bali. In fact, 4.122.205 tourists visited the city of Yogyakarta in 2015 based on the data of the Department of Tourism and Culture of the City of Yogyakarta. The number of visits was divided into two sections, namely 3.813.720 (92\%) domestic tourists, and $308.485(8 \%)$ foreign tourists. These figures increased at the end of 2011, whereas the total number of tourists visiting Yogyakarta City was 1.607.694 as shown in the graph (according to the 2015 tourism data).

The development of Yogyakarta's tourism is inseparable from the diverse types of existing tourism objects, the openness of the people of Yogyakarta, and the role of the government to support the growth of the tourism industry in the city of Yogyakarta. This potential tourism illustrates a conducive destination that has a market value in the tourism sector. Yogyakarta is the second largest tourist destination after Bali. A wide variety of 
tourism objects is developed in this region, such as natural tourism, historical tourism, cultural tourism, educational tours, culinary tours, and night tours. For that reason, Yogyakarta is called a miniature of Indonesia.

Culinary tourism is one of the Yogyakarta's assets for tourists, but this asset needs improvement, development, utilization and conservation. That is why, preservation and development efforts in the culinary tourism are strongly needed, in particular, the prevailing cultural norms and values in Yogyakarta. The Yogyakarta's culinary tourism can influence the development of Yogyakarta's tourism. In addition to the types of tours, the culinary tourism can be aligned with other tours. Promotion is an important thing to do in order to improve the development of culinary tourism in Yogyakarta.

Regional food is now growing rapidly and and it becomes a regional characteristic. In modern life, there are things called traditions, but those traditions are unnecessarily outdated or old-fashioned. Many people long for the past events to come back to this moment of modern time. A culinary describes the local identity of a culture that characterizes environments and habits. It also epitomizes the representation, regulation, consumption and production. A culinary represents a resistance of the community deplete with a variety of meanings that shows social, economic and consumer classy backgrounds. Therefore, in the culinary system, a society manages customary regulations that deal with recommendations, restrictions and ethics on the procedures for their use.

Traditional culinary is one of the results of cultural activities in a community. Hence, culinary and culture are inseparable from each other. Both are united in a cultural structure consciously driven by the community. Tourism and food are ideal duets when the tourism requires food, in line with the nature as humans or tourists depend of food to survive. This culinary asset can be developed as an alternative tourist attraction, which can help the government in increasing tourist visits to areas that have potentially been developed into new tourism areas.

\section{Method}

The research method or approach is mainly concerned with profiles and realities in using qualitative quantum horizons. The research method is based on the identification of traditional culinary culture as an observed reality. This research is intended to describe behaviors, perceptions, motivations, actions, etc., holistically, and within a special natural context. The method used in this research used three kinds of data collection methods, namely in-depth interviews, direct observations, and written documents, diaries, research records, and documentation.

\section{Discussion}

Kotagede house has been built since hundreds of years ago. It means that Kotagede has used a high technology since a long time ago. The uniqueness of Kotagede can be viewed from traditional architectural settlements that include the so-called paths and harmonious roads that exist today. Tourist always visit this traditional site, and they come to see the heritage, buy silver crafts, enjoy traditional villages and homes, and feel the condition of the community. Besides having Islamic characteristics, Javanese and Kalang houses are a result of 
traditional architecture concepts. Such paths and harmonious roads are very unique because they cannot be found anywhere else.

Kotagede has a past history as Kotaraja, the capital city of the Islamic Mataram Palace. Therefore, the history of the civilization concerning the Islamic Mataram cannot be separated from the existence of Kotagede. In its development, Kotagede finally became a city that has traditional cultural potentials, namely: (1) The historical potential of the remaining Mataram kingdoms such as mosque complexes, bathing complexes, Panembahan Senopati and Batu Gilang tombs. (2) The potential in terms of environments and architects, namely many traditional Javanese houses strengthened by the traditional Javanese breathing environment. (3) The potential of traditional arts and crafts, such as many silver craftsmen. (4) The potential of social movements, and the emergence of community movements in Kotagede. (5) The potential of a traditional culinary. (6) Kotagede's traditional cuisine grows and develops along with the dynamics of its history. Kotagede food is famous for its typical snacks such as yangko, kipo, legomoro, jadah manten, bikan, kembang waru and banjar cakes (Zubair).

Such potentials in Kotagede have become a cultural force that can attract both local and foreign tourists. The typical food in this region is an integral part of the past history, but it still tastes delicious at the present because it uses a lot of local ingredients such as rice and sticky rice originating from the Special Region of Yogyakarta. Packaging and shapes remain the same as they were in ancient times, and traditional cooking utensils such as brazier, and so on are closely connected to the local wisdom of Indonesia, especially Java.

Other traditional foods are sold at the place of manufacture, and they are also available for sale in the Kotagede's traditional market, Legi Market. As a center of economy and trade, Kotagede Market is managed by Kotagede's communities, and it provides an attraction for traders from outside the Kotagede area. This marks the popularity of the Legi Market's tradition, and Kotagede market looks crowded by traders who are believed to have the meaning for traders to earn more income than ordinary days. This market has become a government policy in the Mataram kingdom as an effort to increase the people's economy equally. Thus, it is necessary to create market days in other markets in Yogyakarta, such as Pahing Market in the Sleman market, and in the Gamping Market. The Legi Market's tradition in Kotagede raises the market name to be Legi Kotagede Market.

The Legi Kotagede Market is unique because it has a special attraction for visitors who want to feel the density of roads, crowds and mingle with the community from a wide variety of circles in Kotagede. In the Legi Kotagede Market, many traditional culinary delights are still preserved today. People in Kotagede think that a traditional food has existed since a long time ago and it continues to preserve. Therefore, it is usually inherited. Local snacks are difficult to find now. In addition to the fewer makers, the market share is increasingly limited. In fact, local snack enthusiasts still exist. The invasion of foreign and contemporary snacks makes the local food market increasingly pressed.

Kotagede traditional cuisine is in the form of typical snacks, including Kipo, Legomoro, Kembang waru, Yangko and so on. Each of these typical snacks has its own philosophy on people's minds up to now. (1) Kipo. It is the name of a famous culinary heritage in the Kotagede area, which has historical and etymological stories. In the past, people often ordered rare types of food but tasted very good. These kinds of food cannot be found in other regions. Kipo has a unique name because it stands for iki opo. The question that is often asked by the visitors is Iki opo. (Javanese: What is this?). This simple questions has an acronym called kipo. It is a snack that has a slightly flattened and elongated shape, and is green, while its size is as big as a thumb. Kipo is used to be a rare snack. This food was first made by Mbah Mangun Irono. The shape is small and it is brownish and green. Since 1986, kipo has been re- 
popularized by Paijem Djito Suhardjo, the daughter of Mbah Mangun Irono, a resident of Kotagede who at that time participated in a food competition with basic ingredients in the form of sticky rice flour. In the cooking competition Mrs. Djito captured the audience's attention. (2) Legomoro is a typical food of Kotagede which is almost the same as the lemper, but it has its own uniqueness in terms of the taste and presentation. Legomoro is usually used innately during the wedding process. This food is carried by men for the bride's family. This is still used as a Kotagede's tradition during the marriage process. "Marriage and the groom's side must bring the legomoro and the waru flower. Lego moro, as the word from indicates, is called hatine lego le moro yo lego (The one who comes experiences keridhoan, and the one who is visited experiences keridhoan). (3) Waru flower has been a heritage cake since the days of Mataram. In the past, this flower became a mainstay of the palace when a wish was addressed, as a banquet or gift for someone proposing for marriage (Javanese: manten). Today flowers are more plentiful for the arisan or besek content and so on. The term waru flower itself is derived from a royal family who wants to make a cake similar to the shape of a waru flower. (4) Kembang waru cake has 8 curves that mean Hasta Brata, and has a unique philosophy that epitomizes eight elements in nature (ether). Eight main paths that must be considered by humans are like Surya or the Sun, Candra or the moon, Kartika or stars, Maruto or wind, Tirta or water, Hagni or fire, Samudera or sea and Lemah or land. They are symbolically interpreted as the deep gratitude to God. Waru flower cake can also be found in the culinary mountain tradition in the Kotagede's carcass, which is performed every year as a series of the Ngaged Sendang Kotagede Tomb. (5) Yangko is believed to be the food of kings and prijajis during the ancient times. Therefore, ordinary people cannot afford to buy it because it is expensive. Even, Yangko is also believed to be the food that Prince Diponegoro brought during his guerrilla war because it can last long, or it will not stale very quickly.

\section{Conclussion}

Many touching sights that become a cultural transformation of contemporary society are organically triggered by the virtual space dimension. Several decades ago people had to wait for days or even weeks to receive letters from distant relations, but the culture of the writing is now being transformed by e-mail. Today e-mail is able to shorten the delivery time to send messages, and it only takes seconds when clicking the enter button, so the email is sent right away. Thus, in its development the library only contains electronic or digital books (e-books) and electronic journals (e-journals) that transform from the ranks of bookshelves into an integrated digitization system. At the moment, there is no need to bother anyone carrying dozens of books from one place to another for the purposes of learning, presentation, creative processes of scientific studies and the like, but hundreds to thousands of books can be accessed quickly and efficiently only with a smartphone that can get the access to the farest extent. This fact is in line with postcolonial studies, one of the academic studies as a result of the thought of reflective theories and postmodern thoughts. Critical and postmodern theories contribute greatly to growing awareness among scientists that in scientific classifications, understanding and research cannot be separated from the influence of interests, power and ideology. [9]

In addition, Benedict Anderson points out "that a form or method of resistance of the masses of the people without politics is carried out by a petty movement to review the modern politics of the superior identity of the (moderate) elite.[10]. The study of social and cultural 
change is understood in depth in the sociology disciplines along with the object of study of social change that includes social changes ranging from micro (interactions between individuals) to macro-social changes such as changes and social structures or social systems, argues that the concept of social change is a change in the structure of a major society that is the presence of behavioral patterns and forms of social interaction that occur within the community[11]. For more than 50 years, cultural studies have become a paradigm cross in social science [12]. The concept is very appropriate for photographing the social changes that occur today that are influenced by the large flow of cyberculture in the exploration of digital communication and simulation technology. He further explicates various objects of study of social changes by defining social change, sociologists, or authors of socio-cultural studies. In this sense, that several dimensions of social change include (1) structural dimensions, (2) cultural dimensions, and (3) interactional dimensions. The power and ideology in postcolonial theories become a topic under discussion that sharpens the perspective of critical theories to look back at social changes. [13].

In general, modern society and a contemporary cultural perspective demand forms and patterns of social interactions as part of social constructions and processes. The social processes, in which an expansion of social interaction patterns arises, determine the system and the form of social relations in accordance with the needs and developing social contexts. That a social interaction so far is understood as a dynamic pattern of social relations and is directly related to individual relations among groups and between a person and a particular community group. [14]. This view is extremely appropriate to examine the social changes triggered by the use of cybercultures products today. Many things are felt and have traces of discovery and invention processes that are influenced by three main things that Koentjaraningrat raises regarding the awareness, quality of expertise, and stimulation of the process of creating something new to meet the needs of society according to the spirit over time. A socio-cultural change from a society constitutes a form of change that develops a simple level of a more complex one through which several evolutionary stages are adapted to existing developments. Like the views of Tylor and Morgan in Ihromi, the evolution of culture is solely determined by conditions (especially technological ones) and cultures. [14]. A plethora of factors concerning socio-cultural changes, and other forms of social changes arise namely evolution, degeneration, acculturation, assimilation, and other explanations of how culture changes develop over time and changes in space.

Haryatmoko, in BASIS Journal, No.11-12, Year 52, November-December (2003) states that the birth of social change deal with some important concepts of Bourdieu, namely habitus, realm, and a variety of capitals. [15]. Bourdieu formulates a concept of habitus as a form of sociological and philosophical analysis of certain behaviors that define social values in relation to humans and the creation of long-term socialization of values, so that it becomes something that settles as a way of thinking and results in persistent behavior patterns in a person that in turn can be a mental characteristic. The virtual learning technologies into their teaching pedagogy to enhance learning and teaching in this current global world. [16]. Habitus grows in the soul of community naturally through a very long systematic, internalized, and structured social process in the community as a habit in the end. Bourdieu asserts that habitus is not the result of a free will or is determined by structure, but it is created by an interaction between time: dispositions that are both shaped by past events and structures. All those matters are perceived conditions.

Jenkins and Richard [17]. state that intellectual progress (education), social class, prestige and other related things are at different levels with specifications and concreteness. Two forms of cultural capitals. First, an integrated capital within oneself, namely the results of 
personal work and acquisition of something without realizing it. Second, an objective cultural capital, the accumulation of all cultural wealth (books, works of art) that can be possessed materially and it differs from the capabilities of a symbolic capital. The nature of this capital is institutionalized, becoming a member of certain institutions. [18].

That habitus is a mental structure used by a person to deal with his or her social life. Habitus also describes a number of trends that encourage social actors to react in certain ways. The condition is associated with a particular class of conditions and existence of producing habitus, system of durability, transposed dispositions, structured structures that are predisposed to function as structuring structures, that is, principles that generate and organize practices and representations without presuppositions. [19]. Objectively, this 'regulated' and 'regular' sense means without being in any way the product of obedience to rules, so that it can be collectively orchestrated without being the product of the organizing action of a conductor [20].. Bourdieu cites an example in terms of mastering language, writing or thinking. Artists, writers, or thinkers are said to be able to create their works and thanks to their creative freedom because they are no longer aware of the signs or styles they have integrated into themselves. [15]. The fact today many people are increasingly becoming idolatrous in their own discoveries in the form of smart phones and high-speed computers. In line with the presence of new thoughts, or paradigms, asserts that change comes by itself, not just gradual and evolutionary changes, but also, on the contrary, fast, basic, and drastic ones. [21]. This is partly a process of cultural transformation through the social changes that follow.

The transformation of digital narratives through a virtual space plays a key role in the changing of contemporary culture as a narrative of novelty achieved through a continual process of repetitions. In cultural contexts, changes can be decomposed through various realities that grow in society where these habitus emerge in an anthropological perspective. All elements are used as the main material in the practice of digital simulation and communication is more likely to be rhetoric that shows a new situation regarding death. A new situation that transcends the limits of rhetoric is interpreted and controlled indefinitely by others. This can trigger a proposition that the virtual world is deplete with manipulative and disqualitative presentations and simulations.

Acknowledgment. I would like to thank you my colleagues Moh. Rusnoto Susanto, Rahayu Retnaningsih, Bambang Trisilo Dewobroto, Sugiyamin, and Anselmus Sudirman for their synergistic collaboration in the elaboration process and compilation of this manuscript. Our special thanks go to Institutional Leaders of Sarjanawiyata Tamansiswa University, Postgraduate Program of Yogyakarta State University, Surakarta Institute of Indonesian Arts (ISI), and Postgraduate Program of Yogyakarta Institute of Arts (ISI) for the institutional support in terms of a scientific publication collaboration. It can contribute to dedicating knowledge within globally useful scientific disciplines and publications.

\section{References}

[1] Daru, Winartai. 1996. Makanan Tradisional di DIY dan Sekitarnyall. Dalam majalah Ilmu-ilmu Humaniora III, Yogyakarta; Gadjah Mada University Press.

[2] Ayatrohaedi. 1986. Kepribadian Budaya Bangsa (Local Genius). Jakarta: Pustaka Jaya. Dinas Kebudayaan Provinsi DIY.

[3] 2007.Penyusunan Kebijakan tentang KebudayaanLokal dan Daerah melalui PenyusunanKajian Tata Nilai Budaya DaerahYogyakarta. Yogyakarta: Dinas Kebudayaan.

[4] Endah, Alberthiene. 2012.Jokowi -Memimpin Kota Menyentuh Jakarta. Solo: Tiga Serangkai 
[5] Ernayanti, dkk. 2003. Ensilopedi Makanan Tradisional Di Pulau Jawa Dan Pulau Madura. Deputi Bidang Pelestarian Dan Pengembangan Kebudayaan. Jakarta: Proyek pelestarian dan pengembangan tradisi dan kepercayaan.

[6] Geertz Clifford. 1973, The Interpretation Of Culture, United States of America, Basic Book Inc [7] Marianto Dwi M. 2011. Menempa Quanta Mengurai Seni, Yogyakarta, BP ISI

[8] Mardjono. 2004. Dengan Budaya Jawa Menggarap Dunia Bagi Terwujudnya Indonesia yang Besar dan Jaya. Makalah disampaikandalam Dialog KebudayaanNasional Kerjasama Pusat StudiBudaya dan Puslit PKLH di LembagaPenelitian UNY tanggal 8 desember2004.

[9] Marwito, Tirun. 2004. Kebudayaan Yogya dan Perspektifnya. Makalah disampaikandalam Dialog Kebudayaan NasionalKerjasama Pusat Studi Budayadan Puslit PKLH di Lembaga PenelitianUNY tanggal 8 Desember 2004.

[10] Moleong, Lexy. 2003. Metode Penelitian Kualitatif. Bandung: Remanja Rosdakarya

[11] Musanef. 1995. Manajemen Usaha Pariwisata di Indonesia. Jakarta: PT Agung. Rahyono, F. X. 2009. Kearifan Budaya dalam Kata. Jakarta: Wedatama Widyasastra.

[12] Soenarto. 2004. Kebudayaan Jawa dan Perspektifnya. Makalah disampaikan dalam Dialog Kebudayaan Nasional Kerjasama Pusat Studi Budaya dan Puslit PKLH di Lembaga Penelitian UNY tanggal 8 Desember 2004.

[13] Wagiran, dkk. 2010. ॥Pengembangan Model Pendidikan Kearifan Lokal di Wilayah Provinsi DIY dalam Mendukung Perwujudan Visi Pembangunan DIY menuju Tahun 2025 (Tahun Kedua)\|. Penelitian. Yogyakarta: Biro Administrasi Pembangunan.

[14] Yoeti, Oka A. 1985. Pariwisata Budaya Masalah dan Solusinya. Jakarta: PT. Pradnya Paramita.

[15] 